\title{
Sphingomonas soli sp. nov., a $\beta$-glucosidase- producing bacterium in the family Sphingomonadaceae in the $\alpha-4$ subgroup of the Proteobacteria
}

\section{Correspondence \\ Sung-Taik Lee \\ e_stlee@kaist.ac.kr}

\author{
Deok-Chun Yang, ${ }^{1}$ Wan-Taek Im, ${ }^{2}$ Myung Kyum Kim, ${ }^{2}$ Hiroyuki Ohta ${ }^{3}$ \\ and Sung-Taik Lee ${ }^{2}$ \\ ${ }^{1}$ Department of Oriental Medicinal Material and Processing, College of Life Science, Kyung Hee \\ University, 1 Seocheon, Kihung Yongin, Kyunggi 449-701, South Korea \\ ${ }^{2}$ Environmental and Molecular Microbiology Lab., Department of Biological Sciences, Korea \\ Advanced Institute of Science and Technology (KAIST), Guseong-dong 373-1, Yuseong-gu, \\ Daejeon 305-701, South Korea \\ ${ }^{3}$ Department of Bioresource Science, Ibaraki University College of Agriculture, Ami-machi, \\ Ibaraki 300-0393, Japan
}

\begin{abstract}
Strain $\mathrm{T} 5-04^{\top}$, a Gram-negative, non-spore-forming, rod-shaped bacterium, was isolated from soil of a ginseng field in South Korea and characterized in order to determine its taxonomic position. 16S rRNA gene sequence analysis revealed that strain T5- $04^{\top}$ belongs to the $\alpha-4$ subgroup of the Proteobacteria, and the highest degrees of sequence similarity determined were to Sphingomonas asaccharolytica IFO $10564^{\top}$ (97.5\%), Sphingomonas koreensis JSS26 ${ }^{\top}$ (97.1\%), Sphingomonas mali IFO $15500^{\top}(96 \cdot 7 \%)$ and Sphingomonas pruni IFO $15498^{\top}$ (96.6\%). Chemotaxonomic data revealed that strain $\mathrm{T} 5-04^{\top}$ possesses ubiquinone $\mathrm{Q}-10$ predominantly, $\mathrm{C}_{18: 1}$ as the predominant fatty acid and sphingoglycolipids, all of which corroborate its assignment to the genus Sphingomonas. The results of DNA-DNA hybridization and physiological and biochemical tests clearly demonstrated that strain $\mathrm{T} 5-04^{\top}$ represents a distinct species. Based on polyphasic evidence, T5-04 ${ }^{\top}\left(=\right.$ KCTC $12210^{\top}=$ NBRC $100801^{\top}=$ IAM $15213^{T}$ ) should be classified as the type strain of a novel Sphingomonas species, for which the name Sphingomonas soli sp. nov. is proposed.
\end{abstract}

The genus Sphingomonas was created by Yabuuchi et al. (1990) in order to accommodate Gram-negative, strictly aerobic, chemoheterotrophic, yellow-pigmented and rodshaped bacteria that harbour sphingoglycolipids as cellenvelope components. The genus contained a multitude of species consisting of strains of clinical origin, as well as from a variety of other environments. The relatively diverse species of the genus Sphingomonas have been classified into at least four clusters within the $\alpha-4$ subgroup of the Proteobacteria. The genus Sphingomonas has also been divided into four genera: Sphingomonas sensu stricto, Sphingobium, Novosphingobium and Sphingopyxis (Takeuchi et al., 2001).

Yabuuchi et al. (2002) suggested that the genus Sphingomonas should remain undivided and that the species of Novosphingobium, Sphingobium and Sphingopyxis constitute later homotypic synonyms of species of the genus Sphingomonas. Subsequently, Busse et al. (2003) suggested

The GenBank/EMBL/DDBJ accession number for the $16 \mathrm{~S}$ rRNA gene sequence of strain $T 5-04^{\top}$ is $\mathrm{AB} 166883$. that sym-homospermidine, which is a characteristic marker within the family Sphingomonadaceae, had not been considered in the taxonomic considerations of Yabuuchi et al. (1990, 2002) and strongly advocated the proposal of Takeuchi et al. (2001). Nowadays, a great many articles have adopted the nomenclature of Takeuchi et al. (2001) in their reports of novel species in the genera Novosphingobium (Fujii et al., 2003; Sohn et al., 2004; Tiirola et al., 2005), Sphingobium (Ushiba et al., 2003), Sphingomonas (Busse et al., 2003; Li et al., 2004; Rivas et al., 2004) and Sphingopyxis (Kämpfer et al., 2002; Godoy et al., 2003; Yoon \& Oh, 2005; Yoon et al., 2005). At the time of writing, the genus Sphingomonas sensu stricto contains 28 species with validly published names.

In this study, a strain was isolated from soil of a ginseng field in Daejeon city in South Korea and characterized by polyphasic approaches. The results obtained in this study demonstrate that strain $\mathrm{T} 5-04^{\mathrm{T}}$ can be considered to be a member of the genus Sphingomonas, using the nomenclature provided by Takeuchi et al. (2001). However, it can also 
be clearly distinguished from Sphingomonas species with validly published names; we therefore propose that strain $\mathrm{T} 5-04^{\mathrm{T}}$ should be considered the type strain of a novel Sphingomonas species.

Strain $\mathrm{T} 5-04^{\mathrm{T}}$ was isolated from soil of a ginseng field via direct plating onto R2A agar (Difco). Single colonies on these plates were purified by transferring them onto new plates and subjecting them to an additional incubation for 3 days at $30^{\circ} \mathrm{C}$. One isolate, $\mathrm{T} 5-04^{\mathrm{T}}$, was routinely cultured on $\mathrm{R} 2 \mathrm{~A}$ agar at $30^{\circ} \mathrm{C}$ and maintained as a glycerol suspension $(20 \%, \mathrm{w} / \mathrm{v})$ at $-70^{\circ} \mathrm{C}$.

Extraction of genomic DNA was done using a commercial genomic DNA extraction kit (Core Biosystem). The 16S rRNA gene was amplified from the chromosomal DNA using the universal bacterial primer set $9 \mathrm{~F}$ and $1512 \mathrm{R}$ and purified PCR products were sequenced by GenoTech Co. Ltd (Daejeon, South Korea) (Kim et al., 2005). Full 16S rRNA gene sequences were compiled using SeqMan software (DNASTAR). The 16S rRNA gene sequences of related taxa were obtained from the GenBank database. Multiple alignments were performed with the CLUSTAL X program (Thompson et al., 1997). Gaps were edited in the BioEdit program (Hall, 1999). Evolutionary distances were calculated using the Kimura two-parameter model (Kimura, 1983). The phylogenetic tree was constructed by using a neighbour-joining method (Saitou \& Nei, 1987) and the maximum-parsimony method (Fitch, 1972) using the MEGA3 program (Kumar et al., 2004) with bootstrap values based on 1000 replications (Felsenstein, 1985).

The 16S rRNA gene sequence of strain T5-0 $4^{\mathrm{T}}$ was found to be a continuous stretch of 1422 nucleotides. Strain T5-0 $4^{\mathrm{T}}$ was determined to belong to the $\alpha-4$ subgroup of the Proteobacteria, and the highest degrees of sequence similarity were found to be with Sphingomonas asaccharolytica IFO $10564^{\mathrm{T}}$ (97.5\%), Sphingomonas koreensis JSS26 $6^{\mathrm{T}}(97 \cdot 1 \%)$, Sphingomonas mali IFO $15500^{\mathrm{T}}(96 \cdot 7 \%)$ and Sphingomonas pruni IFO $15498^{\mathrm{T}}(96 \cdot 6 \%)$. In the phylogenetic tree (Fig. 1), strain $\mathrm{T} 5-04^{\mathrm{T}}$ clearly belonged to the Sphingomonas lineage, as confirmed by the high bootstrap value.
Cell morphology and motility were observed with a Nikon light microscope $(1000 \times$ magnification $)$, with the cells allowed to grow on R2A agar for 3 days at $30^{\circ} \mathrm{C}$. Gram reactions were conducted according to the non-staining method described by Buck (1982). Catalase activity was determined by bubble production in $3 \%(\mathrm{v} / \mathrm{v}) \mathrm{H}_{2} \mathrm{O}_{2}$ and oxidase activity was determined using $1 \%(\mathrm{w} / \mathrm{v})$ tetramethyl p-phenylenediamine. Acid production from carbohydrates was assessed by the procedures outlined by Cappuccino \& Sherman (2002). Growth at a variety of temperatures $(4,15$, $25,30,37$ and $42{ }^{\circ} \mathrm{C}$ ) was assessed on R2A agar and growth at a variety of $\mathrm{pH}$ values was assessed in R2A broth. Substrate utilization as sole carbon source and some physiological characteristics were determined with API 32GN and API 20NE galleries according to the instructions of the manufacturer (bioMérieux).

When strain $\mathrm{T} 5-04^{\mathrm{T}}$ was cultured on R2A agar (Difco) at $30{ }^{\circ} \mathrm{C}$, it produced yellowish coloured, circular and nonglossy colonies. Cells were aerobic, Gram-negative, nonmotile rods. The strain was able to grow at $15-37^{\circ} \mathrm{C}$, but did not grow at 4 or $42{ }^{\circ} \mathrm{C}$. Results regarding the physiological characteristics of strain $\mathrm{T} 5-04^{\mathrm{T}}$ are summarized in the species description and a comparison of selective characteristics with related type strains is shown in Table 1.

Isoprenoid quinones were extracted with chloroform/ methanol $(2: 1, \mathrm{v} / \mathrm{v})$, purified via TLC and subsequently analysed by HPLC as described previously (Collins \& Jones, 1981; Shin et al., 1996). Cellular fatty acids were analysed in organisms grown on trypticase soy agar (TSA; Difco) for 2 days. Cellular fatty acids were saponified, methylated and extracted according to the protocol of the Sherlock Microbial Identification System (MIDI, 1999). The fatty acids analysed by GC (Hewlett Packard 6890) were identified by the Microbial Identification software package. Total cellular lipids were extracted three times from $50 \mathrm{mg}$ dried cells with $5 \mathrm{ml}$ chloroform/methanol $(2: 1, \mathrm{v} / \mathrm{v})$ and a portion of the extracted lipids was subjected to mild alkaline hydrolysis with $0.5 \mathrm{M} \mathrm{KOH}$ in chloroform/methanol $(2: 1, \mathrm{v} / \mathrm{v})$ for $1 \mathrm{~h}$ at $40^{\circ} \mathrm{C}$ as described by Yabuuchi et al. (1990). Both total extracted lipids and their alkaline hydrolysates were analysed

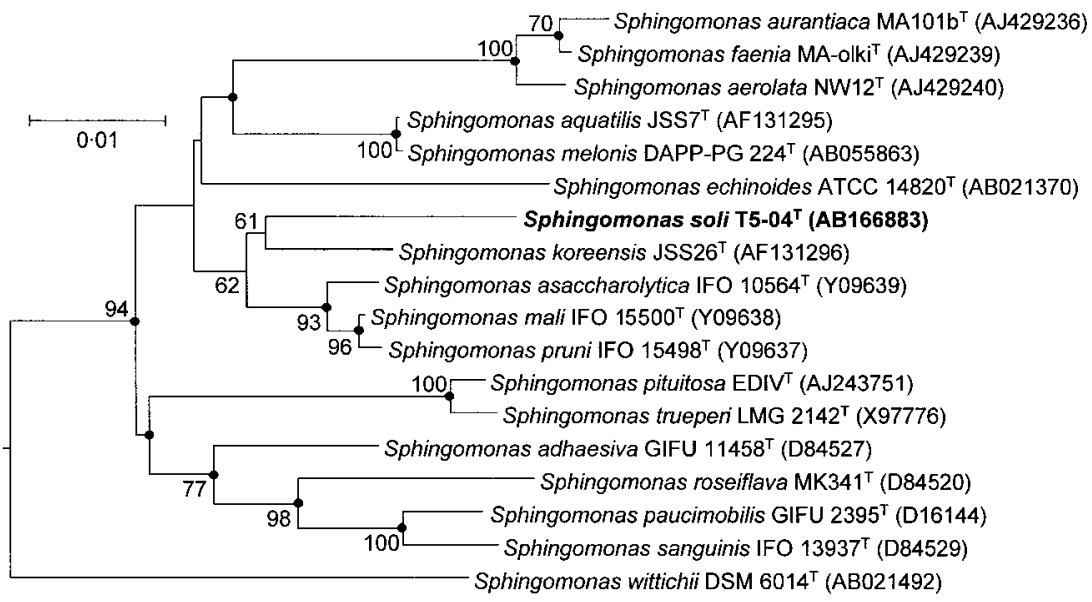

Fig. 1. Phylogenetic tree based on $16 \mathrm{~S}$ rRNA gene sequences, showing the phylogenetic relationships between strain $\mathrm{T} 5-04^{\top}$ and related species (neighbour-joining method). Bar, 0.01 substitutions per nucleotide position. Dots indicate branches that were also recovered by using the maximumparsimony algorithm. Bootstrap values (expressed as percentages of 1000 replications) greater than $60 \%$ are shown at branch points. 
Table 1. Differential phenotypic characteristics between strain $T 5-04^{\top}$ and related taxa

Taxa: 1, Sphingomonas soli sp. nov. T5-04 ${ }^{\mathrm{T}} ; 2$, Sphingomonas asaccharolytica IFO $10564^{\mathrm{T}}$ (data from Takeuchi et al., 1995); 3, Sphingomonas koreensis JSS26 $^{\mathrm{T}}$ (Lee et al., 2001); 4, Sphingomonas mali IFO $15500^{\mathrm{T}}$ (Takeuchi et al., 1995); 5, Sphingomonas pruni IFO $15498^{\mathrm{T}}$ (Takeuchi et al., 1995); 6, Sphingomonas paucimobilis (Yabuuchi et al., 1990). +, Positive; -, negative; W, weak reaction; ND, not determined. PNPG, $p$-Nitrophenyl $\alpha$-D-glucopyranoside. All strains are Gram-negative, yellow, rod-shaped bacteria and are positive for assimilation of D-glucose and maltose. All strains are negative for nitrate reduction, indole production, arginine dihydrolase and urease activity and assimilation of 2-ketogluconate, 3-hydroxybenzoate, caprate, citrate, itaconate, malonate, phenylacetate, propionate, D-ribose, myo-inositol, D-mannitol and D-sorbitol.

\begin{tabular}{|c|c|c|c|c|c|c|}
\hline Characteristic & 1 & 2 & 3 & 4 & 5 & 6 \\
\hline Motility & - & + & + & + & + & - \\
\hline \multicolumn{7}{|l|}{ Enzyme activities: } \\
\hline Oxidase & + & + & + & + & + & - \\
\hline Protease (gelatin hydrolysis) & + & - & - & - & - & + \\
\hline$\beta$-Galactosidase (PNPG hydrolysis) & - & + & + & + & + & + \\
\hline$\beta$-Glucosidase (aesculin hydrolysis) & + & + & - & + & + & + \\
\hline \multicolumn{7}{|l|}{ Carbon assimilation: } \\
\hline 3-Hydroxybutyrate & - & ND & ND & + & + & $\mathrm{ND}$ \\
\hline 4-Hydroxybenzoate & - & ND & ND & + & - & ND \\
\hline 5-Ketogluconate & - & $\mathrm{ND}$ & - & + & - & $\mathrm{ND}$ \\
\hline Acetate & + & - & $\mathrm{ND}$ & + & $\mathrm{W}$ & - \\
\hline Adipate & - & - & - & + & - & - \\
\hline Gluconate & - & - & - & + & + & + \\
\hline DL-Lactate & - & - & ND & - & - & $\mathrm{ND}$ \\
\hline Malate & - & - & + & + & - & + \\
\hline Suberate & - & $\mathrm{ND}$ & ND & + & + & $\mathrm{ND}$ \\
\hline Valerate & - & ND & ND & - & + & ND \\
\hline L-Arabinose & + & + & - & + & + & + \\
\hline L-Fucose & - & ND & ND & + & + & ND \\
\hline D-Mannose & - & + & - & + & + & + \\
\hline D-Melibiose & - & + & + & + & - & + \\
\hline L-Rhamnose & - & + & + & + & + & + \\
\hline Sucrose & + & - & + & + & + & + \\
\hline L-Alanine & - & ND & ND & + & + & - \\
\hline L-Histidine & - & ND & ND & + & + & ND \\
\hline$N$-Acetylglucosamine & - & + & + & + & + & + \\
\hline Salicin & - & - & + & + & + & + \\
\hline L-Proline & - & ND & ND & - & - & $\mathrm{ND}$ \\
\hline L-Serine & - & ND & ND & - & - & $\mathrm{ND}$ \\
\hline DNA G $+\mathrm{C}$ content $(\mathrm{mol} \%)$ & $63 \cdot 9$ & $64 \cdot 8$ & 66 & $65 \cdot 4-65 \cdot 9$ & $65 \cdot 4$ & $63 \cdot 7$ \\
\hline
\end{tabular}

by TLC (HPTLC plate, Silica gel $60,10 \times 10 \mathrm{~cm}$; Merck) with a solvent system composed of chloroform, methanol and water $(70: 30: 5$, by vol.). To detect glycolipid spots, orcine-sulfuric acid reagent $(0 \cdot 2 \%$ orcinol in $2 \mathrm{M}$ sulfuric acid) was sprayed and charred at $120^{\circ} \mathrm{C}$ until the maximum purple colour developed.

The genomic DNA of strain $\mathrm{T} 5-04^{\mathrm{T}}$ was extracted and purified with the Qiagen Genomic-tip system 100/G and was then enzymically degraded into nucleosides, as described previously (Mesbah et al., 1989). DNA-DNA hybridization was performed fluorometrically, according to the method developed by Ezaki et al. (1989), using photobiotin-labelled
DNA probes and microdilution wells. Hybridization was conducted in five replications for each sample. The highest and lowest values obtained for each sample were excluded and DNA relatedness values are expressed as the means of the remaining three values.

The cellular fatty acid profiles of strain $\mathrm{T} 5-04^{\mathrm{T}}$ and related Sphingomonas type strains are shown in Table 2. The major cellular fatty acids in strain $\mathrm{T} 5-04^{\mathrm{T}}$ included summed feature 7 , which includes isomers of octadecenoic acid $\left(\mathrm{C}_{18: 1}\right.$, $65 \cdot 5 \%)$, and hexadecanoic acid $\left(\mathrm{C}_{16: 0}, 14 \cdot 3 \%\right)$. Minor amounts of the 2-hydroxy fatty acids $\mathrm{C}_{14: 0} 2-\mathrm{OH}(3 \cdot 4 \%)$ and $\mathrm{C}_{15: 0} 2-\mathrm{OH}(0 \cdot 9 \%)$ were also determined to be present. 
Table 2. Cellular fatty acid profiles of strain $T 5-04^{\top}$ and related taxa

Taxa: 1, Sphingomonas soli sp. nov. T5- $04^{\mathrm{T}} ; 2$, Sphingomonas asaccharolytica IFO $10564^{\mathrm{T}}$; 3, Sphingomonas koreensis $\mathrm{JSS}^{\mathrm{T}}{ }^{\mathrm{T}}$; 4, Sphingomonas mali IFO $15500^{\mathrm{T}}$; 5, Sphingomonas pruni IFO $15498^{\mathrm{T}}$; 6, Sphingomonas paucimobilis. Data were obtained in this study with the exception of column 6 (taken from $\mathrm{Li}$ et al., 2004). Values are percentages of total fatty acids. For unsaturated fatty acids, the position of the double bond is located by counting from the methyl $(\omega)$ end of the carbon chain. cis and trans isomers are indicated by the suffixes $c$ and $t$, respectively.

\begin{tabular}{|lrrrrrr|}
\hline Fatty acid & $\mathbf{1}$ & $\mathbf{2}$ & $\mathbf{3}$ & $\mathbf{4}$ & $\mathbf{5}$ & $\mathbf{6}$ \\
\hline Saturated fatty acids & & & & & & \\
$\mathrm{C}_{14: 0}$ & & & $1 \cdot 4$ & $16 \cdot 8$ & $4 \cdot 9$ & $1 \cdot 4$ \\
$\mathrm{C}_{15: 0}$ & $0 \cdot 8$ & $3 \cdot 8$ & $0 \cdot 2$ & & $2 \cdot 8$ & \\
$\mathrm{C}_{16: 0}$ & $\mathbf{1 4 \cdot 3}$ & $\mathbf{7 \cdot 5}$ & $\mathbf{1 0 \cdot 9}$ & $\mathbf{1 6 \cdot 9}$ & $\mathbf{1 9 \cdot 3}$ & $\mathbf{8} \cdot \mathbf{7}$ \\
$\mathrm{C}_{17: 0}$ & & $8 \cdot 9$ & & & $4 \cdot 3$ & \\
$\mathrm{C}_{18: 0}$ & $0 \cdot 5$ & $0 \cdot 4$ & $0 \cdot 5$ & & $2 \cdot 6$ & \\
Unsaturated fatty acids & & & & & \\
$\mathrm{C}_{16: 1}$ & & & $1 \cdot 4$ & & & \\
$\mathrm{C}_{17: 1}$ & $9 \cdot 6$ & $27 \cdot 5$ & $1 \cdot 7$ & $4 \cdot 9$ & $12 \cdot 6$ & $3 \cdot 0$ \\
$\mathrm{C}_{18: 1} \omega 5 c$ & & & $1 \cdot 8$ & & $2 \cdot 8$ & $3 \cdot 2$ \\
Summed feature $7^{*}$ & $\mathbf{6 5} \cdot \mathbf{5}$ & $\mathbf{5 0 \cdot 2}$ & $\mathbf{6 9 \cdot 2}$ & $\mathbf{5 8 \cdot 4}$ & $\mathbf{5 0 \cdot 1}$ & $\mathbf{7 4 \cdot 6}$ \\
Hydroxy fatty acids & & & & & & \\
$\mathrm{C}_{14: 0}$ 2-OH & $3 \cdot 4$ & $0 \cdot 4$ & $9 \cdot 8$ & & & $6 \cdot 4$ \\
$\mathrm{C}_{15: 0}$ 2-OH & $0 \cdot 9$ & $1 \cdot 0$ & $0 \cdot 3$ & & & \\
$\mathrm{C}_{16: 0}$ 2-OH & & & $0 \cdot 8$ & & & \\
Summed feature $4^{*}$ & $3 \cdot 9$ & & $2 \cdot 1$ & $2 \cdot 5$ & & $2 \cdot 7$ \\
\hline
\end{tabular}

${ }^{*}$ Summed features designate groups of two or three fatty acids which cannot be separated by GLC with the MIDI system. Summed feature 4 contains $\mathrm{C}_{16: 1} \omega 7 c$ and/or $\mathrm{C}_{15: 1}$ iso 2-OH. Summed feature 7 contains $\mathrm{C}_{18: 1} \omega 7 c, \mathrm{C}_{18: 1} \omega 9 t$ and/or $\mathrm{C}_{18: 1} \omega 12 t$.

The presence of 2-OH fatty acids and absence of 3-OH fatty acids and the presence of octadecenoic acid isomers as major fatty acids are characteristic features of members of the genus Sphingomonas, as has been discussed previously (Godoy et al., 2003). Significant differences in fatty acid profiles were found in Sphingomonas asaccharolytica, Sphingomonas koreensis, Sphingomonas mali and Sphingomonas pruni. Q-10 was the predominant ubiquinone of strain T5-04 ${ }^{\mathrm{T}}$. The quinone system supported our assignment of strain $\mathrm{T} 5-04^{\mathrm{T}}$ to the Alphaproteobacteria, in which the majority of species (including Sphingomonas species) exhibit Q-10 as the predominant quinone (Collins \& Jones, 1981). Strain T5-04 ${ }^{\mathrm{T}}$ was also determined to harbour sphingolipids.

The $\mathrm{G}+\mathrm{C}$ content of the genomic DNA of strain $\mathrm{T} 5-04^{\mathrm{T}}$ was $63 \cdot 9 \mathrm{~mol} \%$. Strain T5-04 ${ }^{\mathrm{T}}$ exhibited relatively low levels of DNA-DNA relatedness to the type strains Sphingomonas asaccharolytica IFO $10564^{\mathrm{T}}$ (22\%), Sphingomonas koreensis $\mathrm{JSS}_{26} 6^{\mathrm{T}}(23 \%)$, Sphingomonas mali IFO $15500^{\mathrm{T}}(20 \%)$ and Sphingomonas pruni IFO $15498^{\mathrm{T}}(12 \%)$. The DNA-DNA hybridization level to related type strains was therefore less than $70 \%$ (Stackebrandt \& Goebel, 1994), which is the suggested threshold which delineates a genomic species. Our results therefore support the assignment of strain $\mathrm{T} 5-04^{\mathrm{T}}$ to a separate, previously unrecognized species.

On the basis of morphological, physiological and chemotaxonomic characteristics, together with data from $16 \mathrm{~S}$ rRNA gene sequence comparisons, strain $\mathrm{T} 5-04^{\mathrm{T}}$ should be placed into a novel species, for which we propose the name Sphingomonas soli sp. nov.

\section{Description of Sphingomonas soli sp. nov.}

Sphingomonas soli (so'li. L. neut. gen. n. soli of soil, the source of the type strain).

Cells are Gram-negative, non-motile, non-spore-forming rods (approx. $1 \mu \mathrm{m}$ in length). They are oxidase-positive, exhibiting oxidative metabolism (obligately aerobic), and catalase-positive. Favourable growth occurs aerobically at $30{ }^{\circ} \mathrm{C}$ on R2A agar, nutrient agar and TSA; optimal growth occurs at $\mathrm{pH} 6 \cdot 8-7 \cdot 5$. Forms yellowish, convex, circular colonies with whole edges on R2A agar within 3 days, approximately $1.5-3.0 \mathrm{~mm}$ in diameter. Q-10 is the predominant quinone. The major cellular fatty acids include octadecenoic acid $\left(\mathrm{C}_{18: 1}\right)$ and hexadecanoic acid $\left(\mathrm{C}_{16: 0}\right)$. Sphingoglycolipids are also present. The $\mathrm{G}+\mathrm{C}$ content of the genomic DNA is $63.9 \mathrm{~mol} \%$ (determined by HPLC). Carbon and nitrogen source utilization and enzyme activities are shown in Table 1.

The type strain, T5-0 $4^{\mathrm{T}}\left(=\right.$ KCTC $12210^{\mathrm{T}}=\mathrm{NBRC} 100801^{\mathrm{T}}=$ IAM $15213^{\mathrm{T}}$ ), was isolated from soil of a ginseng field in Daejeon, South Korea.

\section{Acknowledgements}

This work was supported by the Agricultural R\&D Promotion Center Program (ARPC), Ministry of Agriculture and Forestry, South Korea.

\section{References}

Buck, J. D. (1982). Nonstaining (KOH) method for determination of Gram reactions of marine bacteria. Appl Environ Microbiol 44, 992-993.

Busse, H.-J., Denner, E. B. M., Buczolits, S., Salkinoja-Salonen, M., Bennasar, A. \& Kämpfer, P. (2003). Sphingomonas aurantiaca sp. nov., Sphingomonas aerolata sp. nov. and Sphingomonas faeni sp. nov., air- and dustborne and antarctic, orange-pigmented, psychrotolerant bacteria, and emended description of the genus Sphingomonas. Int J Syst Evol Microbiol 53, 1253-1260.

Cappuccino, J. G. \& Sherman, N. (2002). Microbiology: a Laboratory Manual, 6th edn. San Francisco: Pearson Education, Inc. and Benjamin Cummings.

Collins, M. D. \& Jones, D. (1981). Distribution of isoprenoid quinone structural types in bacteria and their taxonomic implications. Microbiol Rev 45, 316-354.

Ezaki, T., Hashimoto, Y. \& Yabuuchi, E. (1989). Fluorometric deoxyribonucleic acid-deoxyribonucleic acid hybridization in microdilution wells as an alternative to membrane filter hybridization in 
which radioisotopes are used to determine genetic relatedness among bacterial strains. Int J Syst Bacteriol 39, 224-229.

Felsenstein, J. (1985). Confidence limits on phylogenies: an approach using the bootstrap. Evolution 39, 783-791.

Fitch, W. M. (1972). Toward defining the course of evolution: minimum change for a specific tree topology. Syst Zool 20, 406-416.

Fujii, K., Satomi, M., Morita, N., Motomura, T., Tanaka, T. \& Kikuchi, S. (2003). Novosphingobium tardaugens sp. nov., an oestradiol-degrading bacterium isolated from activated sludge of a sewage treatment plant in Tokyo. Int J Syst Evol Microbiol 53, 47-52.

Godoy, F., Vancanneyt, M., Martínez, M., Steinbüchel, A., Swings, J. \& Rehm, B. H. A. (2003). Sphingopyxis chilensis sp. nov., a chlorophenol-degrading bacterium that accumulates polyhydroxyalkanoate, and transfer of Sphingomonas alaskensis to Sphingopyxis alaskensis comb. nov. Int J Syst Evol Microbiol 53, 473-477.

Hall, T. A. (1999). BIOEDIT: a user-friendly biological sequence alignment editor and analysis program for Windows 95/98/NT. Nucleic Acids Symp Ser 41, 95-98.

Kämpfer, P., Witzenberger, R., Denner, E. B. M., Busse, H.-J. \& Neef, A. (2002). Sphingopyxis witflariensis sp. nov. isolated from activated sludge. Int J Syst Evol Microbiol 52, 2029-2034.

Kim, M. K., Im, W.-T., Ohta, H., Lee, M. \& Lee, S.-T. (2005). Sphingopyxis granuli sp. nov., a $\beta$-glucosidase-producing bacterium in the family Sphingomonadaceae in $\alpha-4$ subclass of the Proteobacteria. J Microbiol 43, 152-157.

Kimura, M. (1983). The Neutral Theory of Molecular Evolution. Cambridge: Cambridge University Press.

Kumar, S., Tamura, K. \& Nei, M. (2004). MEGA3: integrated software for molecular evolutionary genetics analysis and sequence alignment. Brief Bioinform 5, 150-163.

Lee, J.-S., Shin, Y. K., Yoon, J.-H., Takeuchi, M., Pyun, Y.-R. \& Park, Y.-H. (2001). Sphingomonas aquatilis sp. nov., Sphingomonas koreensis sp. nov. and Sphingomonas taejonensis sp. nov., yellow-pigmented bacteria isolated from natural mineral water. Int J Syst Evol Microbiol 51, 1491-1498.

Li, Y., Kawamura, Y., Fujiwara, N., Naka, T., Liu, H., Huang, X., Kobayashi, K. \& Ezaki, T. (2004). Sphingomonas yabuuchiae sp. nov. and Brevundimonas nasdae sp. nov., isolated from the Russian space laboratory Mir. Int J Syst Evol Microbiol 54, 819-825.

Mesbah, M., Premachandran, U. \& Whitman, W. B. (1989). Precise measurement of the $\mathrm{G}+\mathrm{C}$ content of deoxyribonucleic acid by highperformance liquid chromatography. Int J Syst Bacteriol 39, 159-167.

MIDI (1999). Sherlock Microbial Identification System Operating Manual, version 3.0. Newark, DE: MIDI, Inc.

Rivas, R., Abril, A., Trujillo, M. E. \& Velázquez, E. (2004). Sphingomonas phyllosphaerae sp. nov., from the phyllosphere of Acacia caven in Argentina. Int J Syst Evol Microbiol 54, 2147-2150.

Saitou, N. \& Nei, M. (1987). The neighbor-joining method: a new method for reconstructing phylogenetic trees. Mol Biol Evol 4, 406-425.
Shin, Y. K., Lee, J.-S., Chun, C. O., Kim, H.-J. \& Park, Y.-H. (1996). Isoprenoid quinone profiles of the Leclercia adecarboxylata KCTC $1036^{\mathrm{T}}$. J Microbiol Biotechnol 6, 68-69.

Sohn, J. H., Kwon, K. K., Kang, J.-H., Jung, H.-B. \& Kim, S.-J. (2004). Novosphingobium pentaromativorans sp. nov., a high-molecular-mass polycyclic aromatic hydrocarbon-degrading bacterium isolated from estuarine sediment. Int J Syst Evol Microbiol 54, 1483-1487.

Stackebrandt, E. \& Goebel, B. M. (1994). Taxonomic note: a place for DNA-DNA reassociation and 16S rRNA sequence analysis in the present species definition in bacteriology. Int J Syst Bacteriol 44, 846-849.

Takeuchi, M., Sakane, T., Yanagi, M., Yamasato, K., Hamana, K. \& Yokota, A. (1995). Taxonomic study of bacteria isolated from plants: proposal of Sphingomonas rosa sp. nov., Sphingomonas pruni sp. nov., Sphingomonas asaccharolytica sp. nov., and Sphingomonas mali sp. nov. Int J Syst Bacteriol 45, 334-341.

Takeuchi, M., Hamana, K. \& Hiraishi, A. (2001). Proposal of the genus Sphingomonas sensu stricto and three new genera, Sphingobium, Novosphingobium and Sphingopyxis, on the basis of phylogenetic and chemotaxonomic analyses. Int J Syst Evol Microbiol 51, 1405-1417.

Thompson, J. D., Gibson, T. J., Plewniak, F., Jeanmougin, F. \& Higgins, D. G. (1997). The CLUSTAL_X windows interface: flexible strategies for multiple sequence alignment aided by quality analysis tools. Nucleic Acids Res 25, 4876-4882.

Tiirola, M. A., Busse, H.-J., Kämpfer, P. \& Männistö, M. K. (2005). Novosphingobium lentum sp. nov., a psychrotolerant bacterium from a polychlorophenol bioremediation process. Int J Syst Evol Microbiol 55, 583-588.

Ushiba, Y., Takahara, Y. \& Ohta, H. (2003). Sphingobium amiense sp. nov., a novel nonylphenol-degrading bacterium isolated from a river sediment. Int J Syst Evol Microbiol 53, 2045-2048.

Yabuuchi, E., Yano, I., Oyaizu, H., Hashimoto, Y., Ezaki, T. \& Yamamoto, H. (1990). Proposals of Sphingomonas paucimobilis gen. nov. and comb. nov., Sphingomonas parapaucimobilis sp. nov., Sphingomonas yanoikuyae sp. nov., Sphingomonas adhaesiva sp. nov., Sphingomonas capsulata comb. nov., and two genospecies of the genus Sphingomonas. Microbiol Immunol 34, 99-119.

Yabuuchi, E., Kosako, Y., Fujiwara, N., Naka, T., Matsunaga, I., Ogura, H. \& Kobayashi, K. (2002). Emendation of the genus Sphingomonas Yabuuchi et al. 1990 and junior objective synonymy of the species of three genera, Sphingobium, Novosphingobium and Sphingopyxis, in conjunction with Blastomonas ursincola. Int J Syst Evol Microbiol 52, 1485-1496.

Yoon, J.-H. \& Oh, T.-K. (2005). Sphingopyxis flavimaris sp. nov., isolated from sea water of the Yellow Sea in Korea. Int J Syst Evol Microbiol 55, 369-373.

Yoon, J.-H., Lee, C.-H., Yeo, S.-H. \& Oh, T.-K. (2005). Sphingopyxis baekryungensis sp. nov., an orange-pigmented bacterium isolated from sea water of the Yellow Sea in Korea. Int J Syst Evol Microbiol 55, 1223-1227. 